\title{
Cultural and Morphological Variation in Sclerotium oryzae Catt. Isolates Collected from Major Rice Growing Areas of Telangana and Andhra Pradhesh States, India
}

\author{
M. Prameela ${ }^{1^{*}}$, B. Rajeswari ${ }^{1}$, D. Krishnaveni ${ }^{2}$, R. Sudhakar ${ }^{3}$, \\ K. Keshavulu ${ }^{4}$ and C. Narender Reddy ${ }^{5}$ \\ ${ }^{1}$ Department of Plant Pathology, College of Agriculture, PJTSAU, Rajendranagar, \\ Hyderabad-30, Telangana state, India \\ ${ }^{2}$ Indian Institute of Rice Research, Rajendranagar, Hyderabad-30, Telangana state, India \\ ${ }^{3}$ Department of Plant Pathology, Administrative office, \\ PJTSAU, Rajendranagar, Hyderabad-30, Telangana state, India \\ ${ }^{4}$ Telangana State Seed Organic Certification Agency, Hyderabad, India \\ ${ }^{5}$ Department of Entomology, College of Agriculture, PJTSAU, Rajendranagar, Hyderabad- \\ 30, Telangana state, India \\ *Corresponding author
}

\section{A B S T R A C T}

\begin{tabular}{|l|}
\hline K e y w o r d s \\
Rice (Oryza sativa \\
$\begin{array}{l}\text { L.), Sclerotium } \\
\text { oryzae, stem rot, } \\
\text { cultural and } \\
\text { morphological } \\
\text { variability }\end{array}$ \\
\hline Article Info \\
\hline $\begin{array}{l}\text { Accepted: } \\
\text { 15 December } 2019 \\
\text { Available Online: } \\
\text { 20 January } 2020\end{array}$
\end{tabular}

\section{Keywords}

Rice (Oryza sativa L.), Sclerotium oryzae, stem rot, cultural and morphological ariability

ticle Info

Accepted:

Available Online:
Cultural and morphological characters of fifteen isolates of Sclerotium oryzae Catt. collected from different rice growing areas in Telangana and Andhra Pradesh states were studied. Significant differences in growth, mycelial dry weights and sclerotial characters were observed among the fifteen isolates grown on PDA and PDB. All the 15 isolates were divided into two groups based on the growth pattern on PDA. Group 1 consists of ten isolates SO2, SO3, SO5, SO6, SO7, SO10, SO11, SO12, SO14 and SO15 which exhibited fast growth rate in terms of colony diameter with a range of $80 \mathrm{~mm}$ to $83 \mathrm{~mm}$. Group II consists of the isolates SO1, SO4, SO8, SO9 and SO13 which recorded moderate growth rate with the colony diameter ranged from 70 to $79 \mathrm{~mm}$. In all the isolates the initiation of sclerotial formation was noticed after 4 to 6 days and the mycelium aggregated into a fullfledged round brown to black sclerotium after 6 to 8 days after inoculation on PDA. Significant differences were observed in sclerotial size in fifteen isolates of $S$. oryzae with a range of $308 \mu \mathrm{m}$ to $1012 \mu \mathrm{m}$ in diameter. In all the isolates the sclerotial formation was initiated from centre towards periphery whereas in the isolate SO1, sclerotia were scattered uniformily. The sclerotia of all the isolates were intermixed in the mycelium except in the isolate SO4 in which sclerotia were formed in circular pattern on the PDA medium. 


\section{Introduction}

Rice is an important cereal food crop which serves as staple food for majority of population in Telangana and Andhra Pradesh states. Different biotic and abiotic factors affects the rice crop under field conditions leading to reduction in crop yields.

Among these, the biotic factors like fungi, bacteria and viruses are the major factors limiting the rice production. Stem rot incited by Sclerotium oryzae which is considered as a minor disease has become major threat in most of the major rice growing areas and causing disease in popular rice cultivars and reduces in quality and quantity of the produce (Gopika et al., 2011). The occurrence of the disease is observed in major rice growing districts of Mahboobnagar, Nalgonda, Warangal and Khammam of Telangana state and Nellore, East Godavari and West Godavari districts of Andhra Pradesh state.

The yield losses to an extent of 80 per cent was reported in different rice cultivars under varied agro climatic regions in India and abroad (Li et al., 1984; Ou, 1985; Cother and Nicol, 1999). Continuous cultivation of rice during different seasons and usage of high dosages of nitrogenous fertilizers and prevalence of graminaceous weed species and inadequate irrigation and drainage facilities increased the stem rot disease incidence (Chen, 1971 and 1973).

Knowledge on naturally occurring pathogen populations is a prerequisite for successful development of new high yielding rice cultivars possessing resistance to stem rot under varied agro climatic situations that are prevailing in Telangana and Andhra Pradesh states. The present investigation has been taken up to study the variations in cultural and morphological characters of 15 isolates of $S$. oryzae collected from rice growing tracts of
Telangana and Andhra Pradesh states.

\section{Materials and Methods}

\section{Isolation and identification of the pathogen}

Extensive roving survey was conducted in major rice growing areas of Telangana and Andhra Pradesh states during kharif, 2015. Samples of rice cv. MTU-3626 ( Prabhat), MTU-1010 (Cottondora sannalu), MTU- 1001 (Vijetha), JGL- 18047 (Bathukamma), NLR34242 ( 91 lavulu ), WGL - 3962 (Bhadrakali) and RNR -15048 (Telangana sona ) exhibiting typical symptoms of stem rot disease were collected.

The infected plant samples were cut into bits of 2-3 $\mathrm{mm}$ size with a sterile blade. These bits were surface sterilized in $0.1 \%$ sodium hypochlorite for 1 to $2 \mathrm{~min}$ and then transferred aseptically to Petri plates containing potato dextrose agar medium and incubated at $25 \pm 1^{\circ} \mathrm{C}$ in a BOD incubator for occurrence of growth and sporulation of the pathogen. The pathogen associated with the disease was identified based on morphological and colony characters as described by Barnett and Hunter (1972). The pathogen was further sub cultured by single sclerotial isolation method on PDA slants for further studies.

\section{Cultural and morphological variability}

The Petri plates containing PDA medium were inoculated with $5 \mathrm{~mm}$ mycelial discs obtained from the periphery of actively growing colony of five days old culture and incubated at $25 \pm 1^{\circ} \mathrm{C}$ in $\mathrm{BOD}$ incubator maintaining three replications. The observations on colony color, colony diameter, hyphal diameter and substrate color were recorded after 5 days of incubation. The mycelial dry weights of $15 \mathrm{~S}$. oryzae isolates 
were recorded by placing $5 \mathrm{~mm}$ mycelial discs obtained from periphery of actively growing colony of five days old cultures in $500 \mathrm{ml}$ conical flasks containing $250 \mathrm{ml}$ of Potato Dextrose Broth (PDB) and incubated at 25 \pm $1{ }^{\circ} \mathrm{C}$ for 10 days maintaining three replications and mycelial mats were filtered on whatman no.1 filter paper and oven dried before recording mycelial dry weights. The data on morphological characters like sclerotial initiation, maturation, color of sclerotia, position and pattern of sclerotia in all the 15 isolates were recorded. The sclerotial initiation (days), sclerotial size in $(\mu \mathrm{m})$ was recorded by measuring 100 sclerotia from each Petri plate using ocular and stage micrometer.

\section{Results and Discussion}

All 15 isolates of $S$. oryzae recorded significant differences in radial mycelial growth of colony and mycelial dry weights on PDA medium. Marked differences were observed among the isolates in cultural characters like growth pattern and pigmentation. On the basis of these characters, all the 15 isolates were divided into two groups.

Where Group 1 consist of the fast growing ten isolates of SO2, SO3, SO5, SO6, SO7, SO10, SO11, SO12, SO14 and SO15 with colony diameter ranged from 80 to $83 \mathrm{~mm}$. Group II isolates are moderately growing consisting of SO1, SO4, SO8, SO9 and SO13 with colony diameter ranged from 70 to $79 \mathrm{~mm}$, respectively. The maximum colony growth was recorded in SO5 isolate $(86 \mathrm{~mm})$ and minimum colony diameter was recorded in SO8 isolate $(70 \mathrm{~mm})$.

The substrate of all the 15 isolates were found whitish to brown in color with folded mycelium on PDA media whereas the mycelium was unfolded in SO1, SO4, SO8,
SO13 and SO15 isolates. The hyphal diameter ranged from $8 \mu \mathrm{m}$ to $15 \mu \mathrm{m}$ in all the fifteen isolates (Table.1).

The formation of sclerotia was observed 4 to 6 days after inoculation on PDA and the mycelium aggregated into a full-fledged round brown to black sclerotium in all the isolates after 6 to 8 days after inoculation on PDA. Significant differences were recorded in sclerotial dimensions with a range of 308 $\mu \mathrm{m}$ to $1012 \mu \mathrm{m}$.

Sclerotial formation was observed from centre towards periphery whereas sclerotia were scattered uniformly on the PDA medium in the SO11 isolate. The sclerotia were mixed in the mycelium in all 15 isolates except SO 4 isolate where as sclerotia were formed in circular pattern on the medium (Table. 2).

Significant differences in sclerotial formation was earlier reported by Ahuja et al., (1987). All the isolates produced sclerotia on PDA medium but the sclerotial initiation period differed (Table. 2). Mundkur (1935) and Punter et al. (1984) who reported that sclerotia were usually produced after one week but it differed in some isolates which produced after 10 days and the large sized sclerotia in culture may be attributed to better availability of nutrition in the medium than on its natural host.

Similar findings in cultural and morphological characters among different isolates of $S$. oryzae were observed by Ali and Singh (1994).

The present study revealed the variation in cultural and morphological characteristics among isolates of $S$. oryzae collected from different districts of Telangana and Andhra Pradesh states. 
Table.1 Cultural characters of S. oryzae isolates collected from different districts of Telangana and Andhra Pradesh state

\begin{tabular}{|c|c|c|c|c|c|c|c|}
\hline Isolates & Place of Collection & $\begin{array}{l}\text { Collected } \\
\text { from } \\
\text { Cultivar }\end{array}$ & $\begin{array}{l}\text { Colony } \\
\text { Color }\end{array}$ & $\begin{array}{l}\text { Colony } \\
\text { Diameter } \\
(\mathbf{m m})\end{array}$ & $\begin{array}{c}\text { Hyphal } \\
\text { Diameter }(\mu \mathrm{m})\end{array}$ & $\begin{array}{c}\text { Mycelial } \\
\text { Dry } \\
\text { Weight (g). }\end{array}$ & Substrate pigmentation \\
\hline SO1 & Jagtial & BPT-5204 & white & 79.07 & 10.07 & 0.95 & Brown and unfolded \\
\hline SO2 & Dharmapuri & BPT-5204 & white & 81.97 & 12.07 & 0.88 & Dark brown and folded \\
\hline SO3 & Mahboobnagar & RNR 15048 & white & 81.93 & 13.97 & 0.82 & White with Folds \\
\hline SO4 & Warangal & BPT-5204 & white & 76.07 & 10.13 & 0.74 & White without Folds \\
\hline SO5 & Nizamabad & BPT-5204 & white & 82.90 & 14.90 & 1.72 & White with Folds \\
\hline SO6 & East Godavari & MTU 3626 & white & 82.07 & 10.07 & 0.93 & White with Folds \\
\hline SO7 & East Godavari & BPT-5204 & white & 81.87 & 15.10 & 1.02 & White with Folds \\
\hline SO8 & Nalgonda & BPT-5204 & white & 69.88 & 10.13 & 0.78 & White to Brownish without Folds \\
\hline SO9 & Nellore & NLR 34242 & white & 77.93 & 8.07 & 0.82 & White to Brown and Folded \\
\hline SO10 & Khammam & MTU 1001 & white & 79.87 & 10.00 & 0.74 & White with Folds \\
\hline SO 11 & Janagam & BPT-5204 & white & 80.07 & 12.13 & 0.73 & White with Folds \\
\hline SO 12 & Mahboobnagar & RNR 15048 & white & 79.73 & 15.10 & 0.88 & White with Folds \\
\hline SO 13 & Ranga Reddy & MTU 1010 & white & 73.93 & 12.07 & 0.96 & White without Folds \\
\hline SO 14 & Ranga Reddy & BPT 5204 & white & 80.13 & 10.07 & 0.79 & White with Folds \\
\hline \multirow[t]{4}{*}{ SO 15} & Khammam & BPT 5204 & white & 79.13 & 10.13 & 0.76 & White to Brownish without Folds \\
\hline & & & CD@5\% & 0.767 & 0.693 & 0.080 & \\
\hline & & & $\mathrm{SE}(\mathrm{m})$ & 0.274 & 0.239 & 0.028 & \\
\hline & & & $\mathrm{CV}$ & 0.578 & 3.566 & 5.313 & \\
\hline
\end{tabular}


Table.2 Morphological characters of fifteen S. oryzae isolates collected from Telangana and Andhra Pradesh state

\begin{tabular}{|c|c|c|c|c|c|c|c|}
\hline S.No. & $\begin{array}{c}\text { Sclerotial } \\
\text { initiation } \\
\text { (days) }\end{array}$ & $\begin{array}{l}\text { Sclerotial } \\
\text { maturation } \\
(\text { days })\end{array}$ & $\begin{array}{c}\text { Sclerotial } \\
\text { dimensions } \\
(\mu \mathrm{m})\end{array}$ & $\begin{array}{l}\text { Sclerotial } \\
\text { color }\end{array}$ & Sclerotial position & Pattern & $\begin{array}{l}\text { Sclerotial } \\
\text { shape }\end{array}$ \\
\hline SO 1 & 5 & 7 & 979.28 & Brown & Center towards periphery & Intermixed within the mycelium & spherical \\
\hline SO 2 & 4 & 6 & 818.23 & Brown & Center towards periphery & Intermixed within the mycelium & spherical \\
\hline SO 3 & 4 & 6 & 308.17 & Brown & Center towards periphery & Intermixed within the mycelium & spherical \\
\hline SO 4 & 5 & 7 & 535.33 & Brown & Center towards periphery & circular pattern above the medium & spherical \\
\hline SO 5 & 4 & 6 & 791.24 & Brown & Center towards periphery & Intermixed within the mycelium & spherical \\
\hline SO 6 & 4 & 6 & 868.18 & Brown & Center towards periphery & Intermixed within the mycelium & spherical \\
\hline SO 7 & 4 & 6 & 1012.25 & Brown & Center towards periphery & Intermixed within the mycelium & spherical \\
\hline SO 8 & 5 & 7 & 764.44 & Brown & Center towards periphery & Intermixed within the mycelium & spherical \\
\hline SO 9 & 5 & 7 & 618.20 & Brown & Center towards periphery & Intermixed within the mycelium & spherical \\
\hline SO 10 & 6 & 8 & 520.22 & Black & Center towards periphery & Intermixed within the mycelium & spherical \\
\hline SO 11 & 5 & 7 & 888.18 & Brown & Scattered uniformly & Intermixed within the mycelium & spherical \\
\hline SO 12 & 5 & 7 & 380.22 & Black & Center towards periphery & Intermixed within the mycelium & spherical \\
\hline SO 13 & 5 & 7 & 919.20 & Brown & Center towards periphery & Intermixed within the mycelium & spherical \\
\hline SO 14 & 4 & 6 & 975.23 & Black & Center towards periphery & Intermixed within the mycelium & irregular \\
\hline SO 15 & 4 & 6 & 460.24 & Brown & Center towards periphery & Intermixed within the mycelium & spherical \\
\hline \multicolumn{3}{|c|}{ CD @5\% } & \multicolumn{5}{|c|}{6.718} \\
\hline \multicolumn{3}{|c|}{ SE (m) } & \multicolumn{5}{|c|}{2.315} \\
\hline \multicolumn{3}{|c|}{ CV } & \multicolumn{5}{|c|}{0.555} \\
\hline
\end{tabular}




\section{References}

AL-Heeti M B and El-Bahadli A H 1982. Estimation of yield losses caused by Sclerotium oryzae Catt. on rice in Iraq. College of Agricultural University Baghdad, Abu Gnarib, Iraq: 113-114.

Ali Z and Singh R A 1994. Variability in Rice stem rot incitant - Magnoporthe Salvinii (Sclerotium oryzae). Indian Journal of Mycology and Plant Pathology 24(1): 38-40.

Barnett H L and Barry B Hunter 1972. Illustrated genera of imperfect fungi. Burgess Publishing Company, Minnesota.

Cother E and Nicol H 1999. Susceptibility of Australian rice cultivars to stem rot fungus Sclerotium oryzae. Australasian Plant Pathology 28 : 85-91.

Gopika K, Jagadeeshwar, Krishna Rao V and Vijayalakshmi K 2016. Salient Research findings on rice stem rot disease (Sclerotium oryzae Catt.) and its management. International Journal of Plant, Animal and Environmental sciences 6(1): 80-82

Hernandez S A 1923. Report of Plant Disease Section. Report, Philippine Bureau of Agriculture 2:159-172.

Srivastava M P, Maheshwari S K and Saini S S 1971.Varietal resistance of rice (Oryzae sativa L.) to stem rot. Indian Journal of Agricultural Science 41 : 93-
7.

Kang M S, Srivastava M P and Maheshwari S K 1970. Studies on stem rot of paddy. Varietal reaction of certain new promising varieties. Journal of Research, PAU, Ludhiana 7 : 587-589.

Li Y G, Kang B J, Feng Y X, Huang D J, Wu D B and Li T F 1984. A brief report on the studies of rice stem rot .Guangdong Agricultural Science $5: 35-37$.

Mundkur B B 1935. Parasitism of Sclerotium oryzae Catt. Indian Journal of Agricultural Sciences 5 : 393-414.

Ou S $\quad$ H 1985. Rice Diseases (2nd edition).Common wealth Mycological Institute, Kew (England), 380pp.

Punter D Reid J and Hopkin A A 1984. Notes on Sclerotium forming fungi from Zizania aquatica (Wild rice) and other hosts. Mycologia 76(4) : 722-732.

Webster R K, Wick C M, Hall D H, Lindberg D and Lindberg A 1972. Effects of various methods of rice residues management on Sclerotium oryzae inoculum level stem rot disease severity and yield, a progress report. Page 59-60 in Proc. 14th Rice Technical Working Group, Univ. of California Davis, June. pp101.

Krause R A and Webster R K 1972. Sclerotial production, viability determination and quantitative recovery of Sclerotium oryzae from soil. Ibid. 64:1333-1337.

\section{How to cite this article:}

Prameela, M., B. Rajeswari, D. Krishnaveni, R. Sudhakar, K. Keshavulu and Narender Reddy, C.. 2020. Cultural and Morphological Variation in Sclerotium oryzae Catt. Isolates Collected from Major Rice Growing Areas of Telangana and Andhra Pradhesh States, India. Int.J.Curr.Microbiol.App.Sci. 9(01): 610-615. doi: https://doi.org/10.20546/ijcmas.2020.901.066 